\title{
THERMAL-DETOXIFICATION EQUIPMENT AND UTILIZATION OF HEAT FROM COKE- BATTERY SMOKESTACK GASES
}

\author{
Ewgen Danilin ${ }^{I}$ \\ Alexander Lobov ${ }^{2}$ \\ 'Kotloenergoprom Stock Company, Ukraine \\ ${ }^{2}$ Coal-Chemistry Institute, Ukraine
}

\begin{abstract}
Kotloenergoprom Stock Co. has developed new technology of thermal rendering harmless and waste recovering of heat of flue gases from coke-oven batteries in one unit.

In 2000, Kotloenergoprom Stock Co. had executed the design of the first in the world Unit of thermal rendering harmless and waste recovering of heat of flue gases from the coke-oven battery No. 1 installed in "Zaporozhkoks" (65 furnaces, $\left.\mathrm{H}=7.0 \mathrm{~m}, \mathrm{~V}=41.6 \mathrm{~m}^{3}\right)$.

The complex "Coke-oven battery - Unit" operates in the special mode using automatic process control system. Introduction the above Unit in 2002 had ensured: decrease of $\mathrm{NO}_{\mathrm{x}}$ contents in flue gases from coke-oven battery in $1.5 \div 2$ times and $\mathrm{CO}$ on $90 \div 100 \%$ with providing international norms of ejections; reburning solid carbon inclusions and combustible components $(\mathrm{H} 2, \mathrm{CH} 4, \mathrm{CmHn})$ in flue gases; stabilization of hydraulic mode of coke-oven battery operation; non-shock putting coke-oven battery into operation directly to chimney stack in case of scheduled or accident stopping the Unit; waste recovery of heat of flue gases from coke-oven battery in quantity up to $6.0 \mathrm{Gkal} / \mathrm{h}$; producing up to $85 \mathrm{tph}$ of steam with energetic parameters at additional combustion of coke-oven gas (without building new chimney stack), that lets to produce additionally $6 \mathrm{MWt}$ of electric power;
\end{abstract}

Standard scheme of producing heat and electric power at by-product coke plants applying usual boiler houses and power stations is irrational. The more effective is to apply the scheme of producing heat and electric power with simultaneous rendering harmless and waste recovery of heat of flue gases from coke-oven batteries in the special Units using existing chimney stacks of coke-oven batteries.

Cost of building the Unit is not more than cost of usual boiler house or power station with equal capacity.

\section{KEYWORDS}

Coke-oven battery; Flue gases; Unit of thermal rendering; Waste recovering; Detoxification 


\author{
Kalmar ECO-TECH '05 and \\ The Second Baltic Symposium on Environmental Chemistry \\ KALMAR, SWEDEN, November 28-30, 2005
}

\title{
MAIN ARTICLE
}

We know that more than $60 \%$ of the toxic atmospheric emissions from coke plants are associated with the coke batteries, and most of those emissions are combustion products of the heating gas discharged through the smokestacks.

The main pollutants are oxides of nitrogen, carbon, and sulfur. Finely disperse carbon particles may also be present. The quantity and composition of the emissions depend on many factors, in particular: the purity of the heating gas; the temperature in the heating channels and the conditions of gas combustion; the design, working life, and operating conditions of the coke batteries; the degree of sealing of the heating-wall lining in the coke chambers and the heating system in the coke batteries; the method of furnace charging; and the environmental-protection systems employed. The coke furnaces are usually heated by means of purified (recycled) coke oven gas and occasionally by blast-furnace gas or a mixture of blast-furnace gas and coke oven gas.

Sulfur dioxide is a combustion product of sulfur compounds in the heating gas. Its content in the smokestack gases largely depends on the degree of removal of sulfur products from the gas. The amount of carbon monoxide released through the coke-furnace smokestacks is determined by the combustion conditions of the heating gas, the temperature, and the sealing of the furnace lining. With an air excess of $>1.3-1.5$, the $\mathrm{CO}$ content in the combustion products is tiny. However, if coke oven gas is drawn from the coking chambers (especially into the zone of the primary heating channels), the combustion conditions may be changed and, with an oxygen deficit, $\mathrm{CO}$ may be formed. Moreover, in furnaces with a limited gas supply, heating gas may be drawn into the low-temperature zone of the heating system, with the appearance of direct (fuel) $\mathrm{CO}$ in the combustion products.

On heating by blast-furnace gas, considerable heating gas may leak through the dividing walls in the regenerators and through the blast-furnace gas valves. This is especially prevalent in coke batteries older than 15-20 years. At furnaces with a limited gas supply, the CO content in the combustion products may reach $0.6 \%$ when heating by coke oven gas, and $1 \%$ when heating by blast-furnace gas.

Nitrogen oxides are formed by complex thermochemical transformations of atmospheric nitrogen and nitrogen-bearing components of the heating gas and their reaction with atmospheric oxygen, with the participation of carbon, hydrogen, and hydrocarbon radicals. Usually, three mechanisms of nitrogen-oxide formation are considered: thermal, high-speed, and fuel mechanisms [1-3]. For thermal oxides of nitrogen, NO formation is mainly determined by the temperature, since the corresponding activation energy is relatively high [2-5]. When the temperature in the heating channel is increased from 1250 to $13508 \mathrm{C}$ (the actual temperature in coke furnaces), the NO content in a theoretical volume of combustion products with an air excess $\mathrm{a}=1$ increases by around $12 \%$ [6J. With increase in a, as in operational coke furnaces, this increase is greater: 40$60 \%$ or more when a $=1.4$.

The high-speed mechanism of NO formation involves bijiding of the nitrogen with hydrocarbon radicals in reactions with very low activation energy. These nitrogen oxides are formed at the end 
of the flame at relatively low temperatures. Their concentration does not much depend on a or the temperature. The most likely mechanism here is associated with hydrocarbon radicals. The yield of nitrogen oxides in comparable conditions ( $\mathrm{a} \sigma \mathrm{l}$ ) is 1.3 times higher in $\mathrm{CH}_{4}$ combustion than in $\mathrm{CO}$ combustion and 12 times higher than in $\mathrm{H}_{2}$ combustion. The yield of such nitrogen oxides is $120 \mathrm{mg} / \mathrm{m}^{3}$ and, as a result, cannot be reduced by stepwise gas combustion $[2-5,7,8]$.

The fuel mechanism of nitrogen-oxide formation involves the combustion of fuel with components that contain nitrogen: ammonia, cyanides, and rhodanides, in the case of coke oven gas. Moreover, with gas leakage, NO formation from nitrogen-bearing components of small coal particles is possible. The yield of such NO depends relatively little on the temperature and is more significant at relatively low combustion temperatures. This mechanism corresponds to the zone where the high-speed mechanism operates, in the initial section of the flame, before thermal NO formation sets in. The conversion of nitrogen-bearing fuel components to NO is sharply increased with increase in a. The NO yield does not much depend on the type of nitrogen-bearing components. If there is less than $1 \%$ bound nitrogen in the fuel, it is completely converted to NO, $[2-5,9,10]$.

The total content of nitrogen oxides in the smokestack gases of the coke batteries may reach 1000 $\mathrm{mg} / \mathrm{m}^{3}$ or more $[11,12]$.

The carbon particles in the smokestack gases of the coke batteries include soot and fine coke dust. Soot formation in coke-furnace heating is associated with physicochemical processes of thermal decomposition of hydrocarbons and the reaction of carbon particles with steam. Moreover, leakage of dry coke oven gas, tar particles, and fine coal particles through the cokingchamber lining has a considerable influence on the formation of carbon particles in the smokestack gases. The content of carbon particles in the smokestack gases of coke batteries may reach $100 \mathrm{mg} / \mathrm{m}^{3}$.

In the last 20 years, environmental issues in coke production have taken on particular urgency. Environmental-protection systems are now an essential part of coking technology. Environmental standards are becoming every more stringent. One of the most important and most challenging requirements within the European Community is limitation of $\mathrm{NO}$, emissions in the waste gases (to $0.5 \mathrm{~g} / \mathrm{m}^{3}$ or less with $5 \% \mathrm{O}$; content). According to [12], the $\mathrm{NO}, \mathrm{CO}$, and dust content in the smokestack gases of old coke furnaces is 1900,3500 , and $140 \mathrm{~kg} /$ ton of coke, respectively.

To reduce the pollutant content in smokestack gases, various measures are adopted in the heating system at coke furnaces: stepwise supply of heating gas; stepwise air supply; systems recirculating the combustion products; regulation of the pauses in tipping; regulation of the air excess; division of the heating wall into different groups of heating channels; improvement in the regenerative system; forced recirculation of the combustion products in the heating coke oven gas or air.

These measures tend to reduce the pollutant content in coke-battery smokestack gases [11, 12].

At the best new batteries, equipped with systems for standardizing heating-gas combustion, the $\mathrm{NO}, \mathrm{CO}$, and dust content is reduced to 600,500 , and $30 \mathrm{~g} /$ ton of coke, respectively [12]. However, the influence of leaks through the coke-furnace lining and heating system on the 
pollutant content in the smokestack gases increases over time. Moreover, measures to standardize gas combustion in the heating walls of the coke furnaces may only reduce the NO, content in the smokestack gases to a certain level.

Since coking technology depends on relatively high temperatures in the heating channels, ensuring NO, contents of less than $500 \mathrm{mg} / \mathrm{m}^{3}$ (with $5 \% \mathrm{O}_{2}$ content) in the smokestack gases is fairly problematic in existing coke batteries.

Tighter limitations of atmospheric emissions may be expected in the future.

In Europe, many coke batteries have been shut down in response to the stiffer environmental laws and the considerable cost of preventive measures. Whereas in 1980, 104 coke batteries were in operation within the European Community, only 43 remained in 1999. Correspondingly, coke production fell from 68.5 to 32.9 million tons $[11,12]$. In Germany, coke production fell from 40 million tons at 46 coke batteries in 1970 to around 7 million tons at five batteries in 2001 [13].

To reduce emissions in coke production, coke production without the collection of chemical byproducts has been widely promoted recently, i.e., modernized beehive and reverberatory furnaces. This technology accounts for around $15 \%$ of total coke output; around $1 \%$ comes from furnaces with recycling of the waste-gas heat. Such coke batteries operate in the United States, Australia, China, and India. The distinguishing features of this technology are that the furnace operates at reduced pressure, air is supplied directly to the coking chambers, and there is complete burnup of the coke oven gas within each furnace chamber [14-19].

In 1998, on the basis of Sun Coke (USA) technology, coke production with heat recycling, electric-power generation, and smokestack-gas purification went into large-scale operation in furnaces with horizontal loading at the Indiana Harbor Coke plant. In processing 1 million tons of coal per year, this technology generates $75 \mathrm{MW}$ of power. In Germany, Thyssen Krupp EnCoke has developed top-loading furnaces without collection of chemical byproducts. Such furnaces of output 250,000 ton/yr are in operation in Australia [16-19].

However, given that coke combustion occurs at 1200-14008C, this technology, with smokestack emissions, offers no benefits over ordinary coking, since it is difficult to organize stepwise gas combustion, to ensure a rational air excess, to optimize the fuel content of the gas, and so on. Moreover, the concentration of nitrogen-bearing compounds in the initial coke oven gas - i.e., $\mathrm{NO}_{\mathrm{X}}$ production by the fuel mechanism - will have a considerable influence on the $\mathrm{j}$ content in the smokestack gases. 
Figure 1. System for thermal processing of smokestack gases and recycling of the related heat.

According to [14-18], comparison of traditional coking and the technology without collecting chemical byproducts indicates that the overall $\mathrm{NO}$, and $\mathrm{CO}$ emissions are reduced in the latter case, while the yield of suspended solid particles is considerably increased. This casts doubt on the possibility of effective long-term operation of the system for recycling the heat from the smokestack gases. Note also that this method may only be introduced in the construction of new batteries. Moreover, this technology requires coal batch with good sintering properties and takes up considerable space.

The next step in developing this approach would be modernization of heap-coking technology.

In recent years, various methods of smokestack-gas purification have been developed [20-24]. In Japan, to ensure the required level of $\mathrm{NO}_{4}$ emissions, nitrogen oxides are removed from cokebattery smokestack gases in catalytic-reduction systems in a special reactor, with catalytic and noncatalytic reduction at different temperatures [25]. As shown by experience with catalytic purification, this is a fairly complex and expensive system, especially with a considerable quantity of smokestack gases and with a large number of components complicating catalytic nitrogen removal. In these conditions, thermal treatment of the smokestack gases is most expedient.

Currently, the demand for steam in the main coke-production shops is 0.01-0.73 Meal/ton of output, while the power consumption is 2.6-20.6 kW/ton of output. Gas condensation and cooling, benzene removal, sulphur removal, and tar condensation and processing are especially energy-intensive processes. For complex, high-volume production, steam and power consumption are several times greater than for traditional production. Thus, in the production of phthalic anhydride, up to $4.5 \mathrm{M} / \mathrm{cal}$ of steam and up to $1400 \mathrm{~kW}$ of power are consumed for each ton of output. 
Given the considerable demand for steam and power in coking and the relatively high temperature of the smokestack gases $(28 \mathrm{O}-3508 \mathrm{C})$, it is expedient to recycle the heat from thermal treatment of the smokestack gases. The possibility of producing steam with the parameters required for power generation is of particular interest.

In 1999, with the cooperation of specialists from the Coal-Chemistry Institute, the State Scientific-Research and Design Institute of the Coke Industry, and Zaporozhkoks Joint Stock Company, NTP Kotloenergoprom Joint Stock Company (Ukraine) developed a new system for thermal treatment of smokestack gases and recycling of the associated heat [26]. In 2000, a working design was developed for the world's first system ensuring thermal treatment of smokestack gases with recycling of the associated heat, for Zaporozhkoks coke battery 1. Coke battery 1 consists of 65 PVR furnace chambers with lower supply of heating gas and air (furnace height $7 \mathrm{~m}$; useful volume $41.6 \mathrm{~m}^{3}$ ). The coke battery went into operation in 1980, with a design capacity of 910,000 tons of coke per year. The basic system is illustrated in Figure 1.

The smokestack gases from the common horizontal flue of the coke battery are sent to this system, whose main components are a special reactor for thermal treatment of the gases and a steam boiler (designed by NTP Kotloenergoprom). All the smokestack gas from the coke battery is sent to the reactor, together with coke oven gas and air in specified proportions. In selecting the temperature conditions of reactor operation and the theoretical ratio of the gas and air, the composition of the smokestack gases is taken into account, so as to maximize smokestack-gas treatment. The process is governed by an automatic control system with specially developed technological algorithms.

The equipment went into operation in December 2002. Tests of various operating conditions for the coke battery and the new system led to the selection of thermal conditions maximizing the removal of toxic components from the smokestack gases and the recycling of the associated heat. The system ensures: reduction in $\mathrm{NO}_{x}$, content in the smokestack gases from the coke battery by a factor of $1.5-2$, and reduction in $\mathrm{CO}$ content by $90-100 \%$, so as to comply with international emissions standards; combustion of solid carbon inclusions and fuel components $\left(\mathrm{H}_{2}, \mathrm{CH}_{4}\right.$, $\mathrm{C}_{\mathrm{m}} \mathrm{H}_{\mathrm{n}}$ ) in the smokestack gases; stabilization of the hydraulic operating conditions of the coke battery; direct, shock-free, connection of the coke battery to the smokestack in the event of planned or emergency shutdown of the new system (the unit operates with an open gate at the common horizontal flue); recycling of the smokestack gases $(<6.0 \mathrm{Gcal} / \mathrm{hr}$ ); increasing the utilization of the heat from the coke oven gas burned in the unit from $\sim 90 \%$ for ordinary boiler and cogeneration-plant gas to $97 \%$, on account of the partial use of the oxygen in the smokestack gases for combustion of the coke oven gas; generation of up to 85 tons of steam for power generation per hour, with additional combustion of coke oven gas (without the construction of a new smokestack, which meets plant needs for technological steam and permits the additional generation of $6 \mathrm{MW}$ of power.

Operational experience indicates that the conventional generation of thermal and electrical energy at coke plants using conventional boilers and cogeneration plants is irrational. It is more effective to generate thermal and electrical energy with simultaneous treatment of coke-battery smokestack gases and recycling of the associated heat in special equipment, while using the existing smokestacks. 


\section{Kalmar ECO-TECH '05 and \\ The Second Baltic Symposium on Environmental Chemistry KALMAR, SWEDEN, November 28-30, 2005}

Startup of the world's first system for thermal processing of smokestack gases and recycling of the associated heat was a considerable step in the development of powerful technological and power-generation systems based on modern coke batteries with various expected working lives.

\section{REFERENCES}

[1] 1981. Nitrogen oxides in products of fuel combustion. In: Proceedings of the Gas Institute, Academy of Sciences of the Ukrainian SSR. Naukova Dumka, Kiev (in Russian)

[2] Sigal, 1.Ya., 1988. Air Protection in Fuel Combustion. Nedra, Leningrad (in Russian).

[3] Gres, L.P., 2002. Environmental Protection. RNA Dnepr-KhAN, Dnepropetrovsk (in Russian).

[4] Fenimore, C. P., 1972. Comb. Flame 19(2), 289-296.

[5] Sigal, I.Ya., Gurevich, N.A., Lavrentsov, H.M. , 1981. Formation of Nitrogen Oxides in Laminar and Turbulent Combustion: Theory and Practice of Gas Combustion. Nedra, Leningrad, vol. 4, pp. 513-521 (in Russian)

[6] 1986. Notes on the Design of Heating and Thermochemical Furnaces in the Rolling and Tube Shops of Metallurgical Plants, Stal'proekt, Moscow (in Russian).

[7] Fenimore, C. P., 1971. In: Thirteenth Symposium of the Combustion Institute, pp. 373-380.

[8] Sigal, 1.Ya., Dombrovskii, E.G., 1978. Formation of Nitrogen Oxides in Combustion and Reducing Atmospheric Emissions. Naukova Dumka, Kiev (in Russian)

[9] Kryzhanovskii, V. N., Sigal, A.I., 1977. Dynamics of Nitrogen-Oxide Formation in the Low-Temperature Region of a Normal Flame. SPI, Saratov, no. 3, pp. 48-53 (in Russian).

[10] Ots, A.A., Egorov, D. M., Saar, K.Yu, 1982. Formation of nitrogen oxides from nitrogen-bearing compounds. Teploenerg., no. 12, pp. 15-18.

[11] Pyr'ikov, A.N., Vasnin, S.V., Boranbaev, B.M., Kozlov, V.D., 2000. Environmental Protection at Coke Plants. Intermet Engineering, Moscow (in Russian).

[12] Ukhmylova, G.S., 2001. Effectiveness of environmental protection in coke production. Nov. Chern. Metall. za Rubezh. 1, pp. 6-25.

[13] Bertling, H., Killich, H. Y., Lunger, H. B., 2003. Coke battery as a component of a closed metallurgical-plant system. Chern. Met. 2,. 14-22

[14] Heinm, D., 2002. Cokemak. Int. 1, 44-50.

[15] Ukhmylova, G.S., 2002. Environmental protection at the new coke plant at Schwelgern, Germany. Nov. Chern. Metall. Za Rubezh 1, 24-26.

[16] Ukhmylova, G.S., 2002. Promising coking technologies. Nov. Chern. Metall. Za Rubezh 1, 13-17

[17] Ukhmylova, G.S., 2003. Comparison of various coking systems. Nov. Chern. Metall. Za Rubezh 2, 20-25.

[18] Allen, C. P., Huffman, R.P., 2002. AISE Steel Technol. 79 (7/8), 40-49

[19] Ellis, A.R., Schuett, K.I., 1999. Cokemak. Int. 11(1), 40-49

[20] 1984. Thermal and Catalytic Purification of Gas Releases to the Atmosphere: Proceedings of the Gas Institute, Academy of Sciences of the Ukrainian SSR. Naukova Dumka, Kiev, (in Russian)

[21] Skorik, L.D., Yu.V. Ivanov, E.N. Arzummanyan, 1986. Industrial testing of smokestack-gas purification at cogeneration plants. Teploenerg. 7.

[22] Japanese Patent 63-39635, MPK-5 C 10B 45/00, 1986.

[23] Japanese Patent 56-24688, MPK-5 F 23J 15/00, 1983. 
Kalmar ECO-TECH '05 and

The Second Baltic Symposium on Environmental Chemistry

KALMAR, SWEDEN, November 28-30, 2005

[24] Jiyaina, N., 1992. Equipment for removing nitrogen from waste gases. Ekol. Vestn. 3, 1-7.

[25] Khakadzuki, Kh., Kavada, S., Saito, K., 1987. Tetsu-to-Hagane 73(12), 383.

[26] Ukrainian Patent 47140 A F23G7/OO, 2002. 